\title{
Gender violence against woman nursing students: a cross-sectional study
}

\author{
Violência de gênero sofrida por mulheres estudantes de enfermagem: estudo transversal \\ Violencia de género sufrida por estudiantes de enfermería: un estudio transversal
}

\section{Luiza Csordas Peixinho da Silva' ORCID: 0000-0001-7516-8754}

Paula Hino

ORCID: 0000-0002-1408-196X

Rebeca Nunes Guedes de Oliveira" ORCID: 0000-0002-8784-9589

Hugo Fernandes'

ORCID: 0000-0003-2380-2914

'Universidade Federal de São Paulo. São Paulo, São Paulo, Brazil. "Universidade Municipal de São Caetano do Sul. São Caetano do Sul, São Paulo, Brazil.

How to cite this article:

Silva LCP, Hino P, Oliveira RNG, H Fernandes. Gender violence against woman nursing students: a crosssectional study. Rev Bras Enferm. 2021;74(5):e20200539. https://doi.org/10.1590/0034-7167-2020-0539

\section{Corresponding author:} Hugo Fernandes E-mail: hugoenf@yahoo.com.br

EDITOR IN CHIEF: Dulce Barbosa ASSOCIATE EDITOR: Antonio José de Almeida Filho

Submission: $08-08-2020$

Approval: $10-05-2020$

\begin{abstract}
Objective: to identify the sociodemographic profile of nursing students who suffered gender violence and to know the characteristics of the violence that occurred in this population. Method: a cross-sectional study with 91 nursing students from a public university in southeastern Brazil, between September 2019 and January 2020. A sociodemographic questionnaire and the World Health Organization Violence Against Women, section 10 were used. Results: approximately $65 \%$ suffered some form of gender violence during their lifetime, mainly perpetrated by family members. $41.7 \%$ were victims of physical aggression, $23 \%$ suffered sexual harassment, $30.8 \%$ suffered sexual abuse. There was a pattern of intergenerational violence $(p<0.001)$, vulnerability of self-declared lesbians and/or bisexuals ( $p=0.705)$, Christian or evangelical $(p<0.001)$. Conclusion: gender violence was high among those surveyed. The experience of forms of violence can damage students' lives. There is a need for attention from teaching institutions and professors in addressing the theme.

Descriptors: Nursing; Violence; Gender-Based Violence; Education; Women's Health.
\end{abstract}

\section{RESUMO}

Objetivo: identificar o perfil sociodemográfico de estudantes de enfermagem que sofreram violência de gênero e conhecer as características da violência ocorrida nesta população. Método: estudo transversal, com 91 estudantes de enfermagem de uma universidade pública da Região Sudeste do Brasil, entre setembro de 2019 e janeiro de 2020. Utilizou-se um questionário sociodemográfico e o World Health Organization Violence Against Women seção 10. Resultados: aproximadamente $65 \%$ sofreram alguma forma de violência de gênero durante a vida, perpetrada, principalmente, por familiares. $41,7 \%$ foram vítimas de agressão física, $23 \%$ sofreram importunação sexual, 30,8\% sofreram violência sexual. Houve padrão de violência intergeracional ( $p<0,001$ ), vulnerabilidade das autodeclaradas lésbicas e/ou bissexuais ( $p=0,705)$, cristãs ou evangélicas $(p<0,001)$. Conclusão: a violência de gênero foi elevada entre as pesquisadas. A experiência de formas de violência pode gerar danos na vida das estudantes. Há a necessidade de atenção das instituições de ensino e docentes na abordagem do tema.

Descritores: Enfermagem; Violência; Violência de Gênero; Educação; Saúde da Mulher.

\section{RESUMEN}

Objetivo: identificar el perfil sociodemográfico de estudiantes de enfermería que sufrieron violencia de género y conocer las características de la violencia ocurrida en esta población Método: estudio transversal, con 91 estudiantes de enfermería de una universidad pública del Brasil, Sureste, entre septiembre de 2019 y enero 2020. Se utilizó un cuestionario sociodemográfico y la sección 10 de World Health Organization Violence Against Women. Resultados: aproximadamente $65 \%$ sufrió alguna forma de violencia de género durante su vida, perpetrada principalmente por familiares. $41,7 \%$ fueron víctimas de agresión física, $23 \%$ sufrió acoso sexual, 30,8\% sufrió violencia sexual. Hubo un patrón de violencia intergeneracional $(p<0,001)$, vulnerabilidad de lesbianas y/o bisexuales autodeclaradas $(p=0,705)$, cristianas o evangélicas $(p<0,001)$. Conclusión: la violencia de género fue alta entre los encuestados. La experiencia de formas de violencia puede dañar la vida de los estudiantes. Es necesario que las instituciones educativas y los maestros presten atención al abordar el tema.

Descriptores: Enfermería; Violencia; Violencia de Género; Educación; Salud de la Mujer. 


\section{INTRODUCTION}

Gender violence has, in its origins, the inequalities in power relations that are exacerbated and manifest in relations of domination that violate human rights and repress possibilities of exercising citizenship. Thus, gender inequity is a background on which a significant part of these social relations are established, determined by a patriarchal culture that legitimizes female subordination and forges conditions for violence and oppression to occur, distancing women and girls from dignified and fair living conditions ${ }^{(1)}$.

The Inter-American Convention on the Prevention, Punishment, and Eradication of Violence against Women ${ }^{(2)}$ defined violence against women as"any act of gender-based violence that results in, or is likely to result in, physical, sexual, or mental harm or suffering to women, including threats of such acts, coercion or arbitrary deprivation of liberty, whether occurring in public or in private life". In a broader theoretical perspective, gender violence is also defined as a phenomenon that victimizes women, children and adolescents of both sexes, considering the current patriarchal logic, in which men determine patterns, norms and conduct of other social groups with social legitimacy ${ }^{(3)}$.

Although it is a relational phenomenon determined by gender and that can victimize any human being, it is a problem that affects mainly women, or at least it is on them that their most deleterious forms of manifestation are practiced ${ }^{(2-3)}$. Defined as an action of discrimination or aggression, which is stimulated according to individuals' gender, gender violence can cause damage, death, embarrassment or suffering of any origin and can occur in varied environments, from the home to companies or formal institutions ${ }^{(4)}$. In this way, patriarchal construction, which still permeates hegemonic culture, produces social relations that remain centered on the ideals of male power. High rates of violence against women, motivated by sexism or similar forms of discrimination are not uncommon ${ }^{(5-6)}$.

Even with the awareness of gender inequalities, together with the advent of the feminist movement in the $19^{\text {th }}$ century and the greater interest in investigating gender violence in Brazil more closely, this scourge remains ${ }^{(5-6)}$. The search for methods of prevention and care for victims is still not a reality for a large part of the population, generating a low number of complaints to protective institutions, in addition to ineffective implementations of public policies to face the problem ${ }^{(6-7)}$. Despite scientific advances, it is observed that women with different characteristics remain the target of various damages resulting from being a woman. Although university women are part of a small group in society, gender violence can also be found in academic environments, negatively impacting students' lives and affecting their quality of life and academic performance in some way ${ }^{(8)}$. This can also extend to the workplace, including nursing, in which hostile attitudes towards nurses by users, companions or team members are more frequent than in other health professions ${ }^{(8-9)}$.

Studies carried out with health professionals on interventions aimed at women victims of gender violence demonstrate that workers carry, in their practices, construction marks and gender concepts, which can facilitate or hinder coping by health services. Furthermore, the experience of domestic violence by women health professionals is also a finding that influences professional practices, reinforcing the feeling of helplessness before the problem ${ }^{(10)}$. This relationship is paradoxical, since nurses responsible for caring for victims of violence often suffer the same adversities that permeate the lives of women they care for ${ }^{(9,11)}$. Moreover, a portion of these professionals is aware of the care that must be provided; however, not all recognize the physical, moral and social consequences caused by violence. Therefore, they are not free to get involved in situations of violence ${ }^{(11)}$.

A study carried out in India sought to know the perception and the number of female medical and nursing students who suffered violence. The proportion of students who have suffered nocturnal provocations in their lives was $77 \%$, but only $2 \%$ reported it to the police. For most of them, nocturnal provocations were common occurrences in Delhi. The study showed the need to make students more proactive and competent to deal adequately with the violence inflicted on them or their close ones ${ }^{(12)}$.

It is important to highlight that women account for $85 \%$ of the nursing workforce. The construction of this field of action is strongly influenced by the historical process of winning citizenship and its insertion in the university, in the job market, in a process influenced by the logic of sexual division. Challenges, such as precarious work, gender stereotypes, hypersexualization of the nurses' image and lack of social recognition still permeate the reality of work of these professionals, who also face the overload of the triple workday and gender violence, which victimize and leverages their vulnerabilities.

The presented problem raised the focus of this article, which proposes to answer the following question: what are the sociodemographic profiles and characteristics of nursing students who have suffered gender violence and their offenders? It is believed that knowing the characteristics of gender violence situations experienced by nursing students will reveal a socially invisible reality, which allows, in addition to reflections, the recognition of a problem. Facing gender violence presupposes its understanding as well as promoting its visibility in the public sphere.

\section{OBJECTIVES}

To identify the sociodemographic profile of nursing students who suffered gender violence and to know the characteristics of the violence that occurred in this population.

\section{METHODS}

\section{Ethical aspects}

This research complied with the norms of Resolution 466/2012. It was submitted to the Research Ethics Committee of Universidade Federal de São Paulo and approved.

During the entire collection period, only two researchers had access to the data, in order to ensure information reliability and confidentiality. In order to guarantee anonymity and facilitate data tabulation, participants were identified by Arabic numerals according to their entry in the survey. An invitation was made through electronic communication channels, such as WhatsApp ${ }^{R}$ and/or e-mail, made available by the academic secretariat exclusively for the purposes of this research. 


\section{Design, sample, and inclusion and exclusion criteria}

This is an exploratory-descriptive research with a cross-sectional design ${ }^{(13)}$, guided by Strengthening the Reporting of Observational Studies in Epidemiology (STROBE) ${ }^{(14)}$, being carried out with nursing students at Universidade Federal de São Paulo, Brazil Data collection took place between September 2019 and January 2020. Data were collected using instruments made available electronically, as well as the Informed Consent Form. An invitation was made by the principal researcher. The sampling plan was based on the totality of female nursing students regularly enrolled in the four periods of the course $(n=173)$. Calculation took into account $5 \%$ of sampling error and $10 \%$ of confidence level in a homogeneous distribution, establishing a sample of 87 units.

Women (cis or transgender), nursing students regularly enrolled in some of the course series and aged 18 years or more were included. As a selection method, it was chosen for convenience. Those who reported not having minimum computer skills to answer the data collection instruments were excluded.

The questionnaires were sent electronically through the "snowball" strategy; therefore, it is not possible to identify how many women received them. Although the initial sample had 94 participants, one student did not sign the Informed Consent Form and two completed the instrument incompletely. Therefore, the final sample was composed of 91 women.

\section{Collection instruments}

Data were collected through a questionnaire with sociodemographic variables and the application of the World Health Organization Violence Against Women (WHOVAW), section 10"Other Experiences". WHOVAW assesses violence between partners in a viable and reliable way. This was created by the World Health Organization (WHO) MultiCountry team ${ }^{(15)}$, with Brazil, in the figure of the Faculty of Medicine of Universidade de São Paulo, also participating in this production. It is a tool validated in Brazi $^{(16)}$ that contains thirteen items that assess violence in a global and specific way: emotional violence, physical violence, and sexual abuse. Section 10 was chosen because it includes aspects related to the object of this study, such as physical, sexual aggression, child, family or domestic abuse, intergenerational patterns, type of offender and frequency of occurrence, not only by intimate partners. Many women experience different forms of violence, caused by family members, by people they know and/or by strangers, in order to verify characteristics of the violence suffered by nursing students. Moreover, the instrument was designed for exclusive assessment of violence against women and is often used in research on gender. The sociodemographic variables included in the questionnaire were age, skin color, marital status, religion, monthly family income, sexual orientation, characteristics of physical and sexual violence, place of occurrence, number of occurrences, sex of the offender and bond/relationship with offenders. The average response time was 32 minutes.

\section{Analysis of results}

The responses to the questionnaires were tabulated on an Excel 97 or higher spreadsheet. Descriptive and inferential statistical analysis was performed using the Statistical Package for the Social Sciences (SPSS) software, version 21. Qualitative variables were described using absolute and relative frequencies. Fisher's exact test was used to verify the relationship between physical violence and other variables. The significance level adopted was 0.05 (a $<0.05$ ), and Hosmer-Lemeshow test, whose null hypothesis is well adjusted to the model and the alternative hypothesis, is not adequate. For a significance level of $5 \%$, a test $p$ value greater than the significance level accepts the null hypothesis of a welladjusted model, indicating model adequacy.

\section{RESULTS}

Most were single, $(n=80) 87.9 \%$, between 18 and 29 years old, $(n=87)$ 95.6\%, white, $(n=77) 85 \%$, heterosexual, $(n=65) 71.4 \%$, with family income of three to five minimum wages, $(n=18)$ $19.7 \%$, non-practicing Catholic/catholic religion, $(n=19) 20.8 \%$, living with a relative, $(n=68) 74.7 \%$. Also, 28 have been forced into sexual practices since they were 15 years old. About $65 \%$ of those surveyed said they had suffered gender-related violence at some point in their lives, ranging from physical assaults to sexual harassment.

Regarding physical aggression, $41.7 \%(n=38)$ stated that they had been victims since the age of 15 , a time frame established by the $\mathrm{WHO}$, being a family member, the perpetrator in $79 \%(n=30)$ of cases, which allows assessing the degree of kinship prevalent between victim and offender. 17 (18.7\%) stated that this occurred few times. Physical violence was accompanied by sexual abuse in $28.9 \%(n=11)$ of those surveyed. Thus, $50 \%(n=4)$ of those who declared themselves black suffered this aggression. Their family income was between five and nine minimum wages, $42 \%(n=16)$, unlike those surveyed who were sexually assaulted the same age, $31 \%(n=28)$, whose predominant family income was up to five minimum wages, $46 \%(n=13)$. Thus, it was possible to analyze the relationship between income and the type of violence.

Of the 21 (23\%) women who responded to having suffered sexual harassment before the age of $15,66.7 \%(n=14)$ pointed out that perpetrators were family members. Eight (38.2\%) participants suffered from this suffering between the ages of six and eight, a fact that led to the beginning of sexual life and that he was four to 14 years older than them. Six participants stated that their first sexual intercourse was performed due to sexual abuse and that the age group was nine to 15 years old when it occurred. It was also shown that $19 \%(n=4)$ of participants had their mother assaulted by their husband or partner and $42.8 \%$ $(n=9)$ witnessed domestic violence during childhood. Moreover, $37.5 \%(n=3)$ of black women had their mothers beaten by their husbands, against $9 \%(n=7)$, who declared themselves to be white, demonstrating race as an important factor in intergenerational violence. Furthermore, most of sexual offenders of infants are men known to the victims.

Regarding the characteristics of physical violence from the age of 15 , it was found by using Fisher's exact test $(95 \% \mathrm{Cl})$ that the associated variables were: 1 . sexual orientation $-50 \%(n=11)$ of women who self-declared bisexuals suffered violence and $100 \%$ $(n=3)$ of homosexuals $(p=0.037) ; 2$. number of times that suffered physical violence $-94.2 \%(n=16)$ reported having been victims of 
this aggression only a few times, but did not deny it ( $p<0.001)$; 3. family income $-83.3 \%(n=10)$ of participants with an income higher than nine minimum wages did not suffer physical violence $(p=0.02)$, unlike those whose family income was low or medium; 4. intergenerational violence -young people whose mother was assaulted by her husband or partner were also assaulted from the age of 15 ( $p<0.001)$. About $70 \%$ of those who, during childhood, did not witness domestic violence, did not suffer physical violence in their youth $(p=0.003)$.

According to the Odds Ratio estimates presented in Table 1, it is evident that children who had their mothers assaulted by their husbands/partners were approximately 10.5 times more likely to be physically assaulted in adolescence. If, as a child, he or she saw or heard about domestic violence, the chance of suffering such injury increased by approximately 13.7 times, keeping the other variables constant. By Hosmer-Lemeshow test, the model is adequate to the data ( $p$ value $=0.915$ ), as it has an area below the curve of 0.867 , indicating an excellent discrimination.

Since they are considered important characteristics to explain the response variable, despite the great breadth, they were left in the model. Even so, the model proved to be adequate by Hosmer-Lemeshow test and the area under ROC curve.

In relation to sexual abuse, $70 \%(n=7)$ of those who declared themselves evangelical/Christian were victims of this as well as $60 \%(n=3)$ of agnostics/atheists/skeptics ( $p<0.001)$. All were assaulted more than once ( $p<0.001$ ). It was noted that $44.4 \%$ $(n=12)$ initiated sexual life between nine and 16 years old, and all of those who claimed to have been forced to have sex for the first time assured that they had been sexually assaulted since they were 15 . Those who claimed to have suffered more than twice this hostility, they were 28.5 times more likely to continue being assaulted. The other variables remained constant.

Table 1 - Odds Ratio estimates of the reduced multivariate model associated with the characteristics of physical violence, São Paulo, São Paulo, Brazil, 2019

\begin{tabular}{|c|c|c|c|c|}
\hline Characteristic & $\begin{array}{c}\text { Percentage } \\
\text { (\%) }\end{array}$ & $\begin{array}{l}\text { Odds } \\
\text { Ratio }\end{array}$ & $* 95 \% \mathrm{Cl}$ & $\begin{array}{c}* * p \\
\text { value }\end{array}$ \\
\hline $\begin{array}{l}\text { Physical violence since } \\
\text { age } 15 \text { - suffered once } \\
\text { or twice }\end{array}$ & 60.7 & 0.035 & $\begin{array}{l}{[0.005} \\
0.135]\end{array}$ & $<0.001$ \\
\hline $\begin{array}{l}\text { As a child, their mothers } \\
\text { were assaulted by their } \\
\text { husbands/partners }\end{array}$ & 26.3 & 10.489 & $\begin{array}{c}{[1.262 ;} \\
226.738]\end{array}$ & 0.052 \\
\hline $\begin{array}{l}\text { As a child, he or she } \\
\text { saw or heard about } \\
\text { domestic violence }\end{array}$ & 50 & 13.704 & $\begin{array}{c}{[3.008 ;} \\
104.736]\end{array}$ & 0.003 \\
\hline
\end{tabular}

Table 2 shows that being single reduced the chance of sexual harassment by approximately one sixth. Young non-practicing Catholics and non-Catholics are 13 times more likely to suffer from this practice, unlike those who identify themselves as Protestant Christians or non-Christians, who are 8.7 times more likely to have been forced to have sex since the age of 15. Those who live with a family member are also 5.29 times more likely to be sexually assaulted. The model is adapted to the data by Hosmer-Lemeshow Test ( $p$ value $=0.560$ ) and has an area below ROC curve of 0.722 , indicating a reasonable discrimination.
Table 2 - Odds Ratio estimates of reduced logistic multivariate modeling of variables related to sexual abuse in young women, São Paulo, São Paulo, Brazil, 2019

\begin{tabular}{lccc}
\hline Characteristics & $\begin{array}{c}\text { Odds } \\
\text { Ratio }\end{array}$ & $\begin{array}{c}\text { Percentage } \\
\text { (\%) }\end{array}$ & $* 95 \% \mathrm{Cl}$ \\
\hline $\begin{array}{l}\text { Marital status- single } \\
\begin{array}{l}\text { Catholic/non-practicing } \\
\text { Catholic religion }\end{array}\end{array}$ & 0.154 & 78.6 & {$[0.024 ; 0.566]$} \\
$\begin{array}{l}\text { Protestant Christian/Christian } \\
\text { religion }\end{array}$ & 0.076 & 10.7 & {$[0.004 ; 0.409]$} \\
$\begin{array}{l}\text { Resides with a family member } \\
(\mathrm{s}) ; \text { schoolmate }\end{array}$ & 5.291 & 82.1 & {$[1.343 ; 35.346]$} \\
\hline
\end{tabular}

Note: ${ }^{*} \mathrm{Cl}$ - confidence interval.

In cases of sexual harassment, defined as acts of insistence for sexual practices, without the actual means, it was observed that all sexually abused students were also often harassed before the age of $15(p=0.001)$. Approximately $38.1 \%(n=8)$ were between 6 and 8 years old when this occurred for the first time $(p=<0.001)$, and their offenders were older in $47.6 \%(n=10)$ of cases, however with less than 20 years $(p<0.001)$. Abuse occurred more than once in $19.4 \%(n=13)$ of those surveyed $(p<0.001)$. According to Hosmer-Lemeshow test, the chances of continuing to suffer this type of violence was 23.5 times.

Regarding being forced to have their first sexual experience, $9.1 \%(n=2)$ of those who declared themselves to be bisexual reported having been forced $(p=0.705)$, and $23.5 \%(n=4)$ of women physically assaulted since the age of 15 , they also had their first sexual contact in a forced way $(p=0.0169)$. In the light of OR analysis, it was shown that women who suffered physical violence, even if only a few times, since they were 15 years old, had a chance of having their first sexual intercourse almost 11 times greater than those who did not suffer.

Mothers' aggression by fathers or partners was also noted in the study. About $57.2 \%(n=4)$ of those who suffered violence often also had their mothers beaten by their husbands/partners $(p=0.003)$, especially those whose family income was between seven and nine minimum wages $(p=0.005)$. Mothers-in-law' aggression was also identified in $60 \%(n=3)$ of those who had their mother assaulted ( $p$ $<0.001$ ). Those whose mother was beaten by their husband/partner were 12 times more likely to suffer physical violence by a family member than those whose mothers were not beaten. By HosmerLemeshow test, the model is adequate to the data $(p=1)$. The area under ROC curve is $77.2 \%$, indicating a reasonable breakdown.

\section{DISCUSSION}

This study represents a contribution to occurrence identification and factors associated with gender violence suffered by nursing students at a university in southeastern Brazil, from childhood to the present age. The analysis made it possible to draw a sociodemographic profile of the victims. The instrument used sought to investigate the main aggressions associated with gender and motivated by sexism, such as physical, sexual, and harassment. Analysis through the linearity of time allowed to find longitudinal aspects experienced by the participants, which impact on their trajectories and quality of life.

The data showed that, in relation to physical violence experienced since the age of 15 , sexual orientation was a factor of great 
predisposition to aggression. Coinciding with these findings, a study of 316 people who identified themselves as homosexual, bisexual or transgender showed that the association of prejudices reflected in human rights violations and non-heterosexual women were frequently affected by physical violence ${ }^{(17)}$.

According to the Inter-American Commission on Human Rights, lesbian women are at particular risk of violence through misogyny and homophobia; however, there is significant underreporting of violence against women. Thus, of the 770 cases of violence against lesbians and bisexuals between 2013 and 2014, notified by this committee, only 55 cases were against lesbian women. Although this data is in contrast to the findings in the present study, it is understood that this low number can also be attributed to the invisibility of acts of violence against women as well as the fact that most of these acts occur in private environments ${ }^{(18-19)}$.

The study found that physical violence was also related to the fact that the offender is a family member, family income and domestic violence with the mother. The results also revealed a relationship between sexual abuse suffered between six and eight years with income and family ties with offenders. These data are corroborated with the findings of another study that showed the relationship between physical aggression with age, education, marital status and maternal history of intimate partner violence. The research cited also revealed that sexual abuse perpetrated against low-income women reaches police stations, and among the wealthiest, when dealt with, it is done by a therapist ${ }^{(17)}$. A study in Delhi also shows that most students at a university in India do not report cases of violence ${ }^{(12)}$.

In relation to violence against children and adolescents, it is important to consider the articulation between the gender and generation categories. Biological founders like sex and age influence and justify patterns of domination, privileges and inequalities that culminate in violence ${ }^{(17-18)}$. Violence against women manifests itself mainly in the domestic sphere, being committed against disadvantaged people in the power relations established in the family sphere, such as women and children ${ }^{(18)}$. The maintenance of patriarchal values, culturally legitimized in society, can mean an obstacle to girls' and women's lives as citizens, since violence is trivialized and reduced to a phenomenon of everyday life, and there are no possibilities for transformation.

Taking into account the violence that crosses generations, i.e., mothers assaulted by their partners, followed by their daughters also assaulted, there are studies that have shown greater risks of persistence of violence according to the previous family history of violence, in agreement with the findings current research. However, this manifests itself in different ways depending on the vulnerability of these women, attesting that the personal history of violence, when offenders are the fathers, acts in a continuous manner. When violence occurs through an intimate partner, the effect produced can be perpetuated between future generations ${ }^{(18-19)}$. In agreement with the findings of this study, the scientific literature ${ }^{(20-22)}$ mentions that most of sexual offenders of children and adolescents are men known to the victims, being family members, friends or close people. But our findings showed that almost half of rapists were under the age of 20, which is in contrast to what is found in the literature, in which the average age of offenders is 41 years.

Studies point out that early female sexual initiation, as evidenced among the participants in this research, may offer an increased risk of physical problems, such as sexually transmitted infections, genital injuries, psychosocial problems such as difficulty in future relationships or exacerbation of sexuality, in addition to early pregnancy and clandestine abortion ${ }^{(22-23)}$. In accordance with the Odds Ratio used in this study, women who suffered physical violence were more likely to also experience sexual abuse. According to a survey conducted in Pará State, Brazil, physical violence was reported as a precedent for sexual violence, as well as the profile of victims characterized by adolescents, low-income and Catholic, and the latter characteristics do not corroborate our findings, violence physical sexual conduct abuse, portraying sociodemographic differences between northern and southeastern Brazil(24).

This reality, sexual abuse preceded by physical violence, reveals a significant relationship of the determination of violence in the family with inequality of power in the historically constructed gender relations that conform patterns of femininity and masculinity related to submission and domination, since childhood. In families, violence is hardly an isolated problem. There is an overlap of their forms of manifestation (psychological, physical, sexual and patrimonial), often linked to other social vulnerabilities and previous stories of violence ${ }^{(17)}$. It became evident that most victims of some type of aggression were single. This finding can be justified by the age group of participants, who are young. In addition to this possibility, the results call attention to a possible relationship with the fact that having suffered violence during childhood. Experiencing sexual abuse can negatively influence relationships in adulthood. Another study points to the relationship of sexual abuse with exacerbated anxiety production and a tendency to avoid relationships with the opposite sex due to a break in the bond and trust, since the offenders, in general, were not unknown ${ }^{(25)}$.

When analyzing the relationship between aggression against women and religion, it is clear that evangelical women were more likely to have been victims of violence at some stage in life. Also, there is an expressive number of these who reported having been assaulted by their partners, a subject that has been investigated in several studies on gender violence, which demonstrates the relationship between violence and religion ${ }^{(22-27)}$. The present study reveals a high magnitude of gender violence suffered by nursing students who reached a place in higher education at a public university, constituting, in a way, a privileged group, considering that this is not a reality for most Brazilian women.

When violence is practiced against women, adolescents and children, it ends up being part of everyday life, taking over a contradictory meaning, in which the home, culturally represented as a space of protection and in which subjects materialize most of social reproduction, represents exhaustion and violence for girls and women. This leads us to reflect on whether there is, in fact, any social environment in which women are safe, in a context that reiterates the inequalities ${ }^{(28)}$.

\section{Study limitations}

As limitations, it is pointed out that the data were collected in a single public university and that the participants were mostly young, and different results can be found if investigated other populations. Finally, using a cross-sectional study, which focuses on data analysis in a specific period, may not address variables that allow for greater 
data exploration and deepening, but these limitations do not compromise the results and the relevance of the theme. Studies like this bring a new look at the phenomenon of gender violence.

\section{Contributions to nursing and health}

Within the scope of public policies, it may offer theoretical support for the development and planning of strategies for preventing and tackling gender violence based on the recognition of the magnitude and characteristics of the problem among female nursing students in São Paulo. Given the findings of this research, it is believed in the potential that Schools of Nursing and professors have to rethink their formative role, understanding that the debate on gender violence should not occur in a way that is distant from the reality of students, since their experiences, throughout of their stories, they must be taken into account in planning actions, and understood in a human and welcoming way so that they are able to take care of the other and of themselves.

\section{CONCLUSION}

This research sought to identify the sociodemographic profile of the victims and some characteristics of gender violence suffered by female nursing students, verifying that the majority of those surveyed experienced some form of gender violence among those analyzed. Furthermore, it was noted that the intergenerational pattern of violence is a frequent form of manifestation, associated with family violence. Students with sexual orientation other than heterosexual were more vulnerable than the rest, having been forced to have sexual experiences. The precocity of the first sexual experience was also evident. Religion did not show a positive association with injuries. The study has direct implications for sectors interested in tackling violence against women, especially nursing students. It is concluded that gender violence requires intersectoral and multidisciplinary action from childhood to adulthood (age group considered in this research). It is advocated that the State should guarantee the rights of these citizens and promote prevention and coping policies that are implemented in strategies and implemented measures that include from educational institutions to families and society as a whole.

It is hoped that the study will serve to stimulate researchers to carry out studies that will make it possible to deepen the phenomenon of violence against women, filling in the existing gaps and expanding knowledge on the subject. This will also make it possible to give women a voice, expanding strategies to face the problem and favoring a culture of peace.

\section{REFERENCES}

1. Fonseca M, Ferreira M, Figueiredo R, Pinheiro Á. O feminicídio como uma manifestação das relações de poder entre os gêneros. JURIS Rev Fac Direito [Internet]. 2018 [cited 2020 Sep 14];28(1):49-66. Available from: https://periodicos.furg.br/juris/article/view/7680

2. Tavares LA, Campos CH. The Inter-American convention to prevent, punish and eradicate violence against women, "convention of Belém-Pará" and the Maria da Penha law. Interfaces Cient[Internet]. 2018 [cited 2020 Feb 23];6(3):9-18. Available from: https://periodicos.set.edu.br/index. php/humanas/article/view/3536/2672

3. Sifaki A. Which side are we on? feminist studies in the time of neoliberalism or neoliberal feminist studies? Women's Stud Int Forum [Internet]. 2016 [cited 2020 Feb 23];54:111-18. Available from: https://www.sciencedirect.com/science/article/abs/pii/S0277539515000990?via\%3Dihub

4. Villiers T, Mayers PM, Khalil D. Pre-registration nursing students' perceptions and experiences of violence in a nursing education institution in South Africa. Nurse Educ Practice [Internet]. 2015 [cited 2020 Feb 24];14(6):666-73. Available from: https://www.sciencedirect.com/science/ article/abs/pii/S1471595314001206?via\%3Dihub

5. Rodrigues NP, O'Dwyer G, Andrade MKN, Dlynn MB, Monteiro DLM, Lino VTS. The increase in domestic violence in Brazil from 2009-2014. Cienc Saúde Colet [Internet]. 2017 [cited 2020 Feb 24];22(9):2873-80. Available from: https://www.scielo.br/pdf/csc/v22n9/1413-8123-csc-22-09-2873.pdf

6. Parker KF, Stansfield R. The changing urban landscape: interconnections between racial/ethnic segregation and exposure in the study of race-specific violence over time. Am J Public Health [Internet]. 2015 [cited 2020 Feb 25];105(9):1796-805. Available from: https://ajph. aphapublications.org/doi/10.2105/AJPH.2015.302639

7. Simsek HG, Ardahan M. The leavel of recognition of the symptoms of violence against women by senior year nursing and midwifery students. Contemp Nurs[Internet]. 2020 [cited 2020 Feb 25];56:e1737554. Available from: https://doi.org/10.1080/10376178.2020.1737554

8. Tee S, Özçetin YSU, Russell-Westhead M. Workplace violence experienced by nursing students: an UK survey. Nurs Educ Today [Internet]. 2016 [cited 2020 Jan 22];41:30-5. Available from: https://www.sciencedirect.com/science/article/abs/pii/S0260691716001209?via\%3Dihub

9. Budden L, Birks M, Cant R, Bagley T, Park T. Australian nursing students' experience of bullying and/or harassment during clinical placement. Collegian [Internet]. 2017 [cited 2015 Jul 23];24(2):125-33. Available from: https://www.collegianjournal.com/article/S1322-7696(15)00116-X/ fulltext

10. Saletti-Cuesta L, Aizenberg L, Ricci-Cabello I. Opinions and experiences of primary healthcare providers regarding violence against women: a systematic review of qualitative studies. J Fam Viol [Internet]. 2018 [cited 2020 Feb 20];33:405-20. Available from: https://link.springer.com/artic le/10.1007\%2Fs10896-018-9971-6

11. Silva $C M$, Gomes VLO, Fonseca AD, Gomes $M T$, Arejano CB. Representation of domestic violence against women: comparison among nursing students. Rev Gaúcha Enferm [Internet]. 2018 [cited 2020 Mar 01];39e63935. Available from: https://www.scielo.br/pdf/rgenf/v39/en_19831447-rgenf-39-e63935.pdf 
12. Gautam N, Anand T, Kishore J, Grover S. Experience of violence amongst female medical and nursing students and their perception regarding violence against women in Delhi, India [Internet] 2017 [cited 2019 Nov 23];32(3):e20170130. Available from: https://doi.org/10.1515/ ijamh-2017-0130

13. Bhopal RS. Concepts of epidemiology: integrating the ideas, theories, principles, and methods of epidemiology. 3th ed. Oxford: University press, 2016.

14. Cuschieri S. The STROBE guidelines. Saudi J Anaesth [Internet] 2019 [cited 2020 Sep 15];13(1):31-4. Available from: https://www.ncbi.nlm.nih. gov/pmc/articles/PMC6398292/

15. Garcia-Moreno C, Jansen HA, Ellsberg M, Heise L, Watts CH. Prevalence of intimate partner violence: findings from the WHO multi-country study on women's health and domestic violence. Lancet [Internet] 2006 [cited 2019 Aug 11];368(9543):1260-9. https://doi.org/10.1016/ S0140-6736(06)69523-8

16. Schraiber LB, Latorre MRDO, França Jr. I, Segri NJ, D'Oliveira AFPL. Validity of the WHO VAW study instrument for estimating gender-based violence against women. Rev Saúde Pública. 2010;44(4):1-9. https://doi.org/10.1590/S0034-89102010000400009

17. Parente JS, Moreira FTLS, Albuquerque GA. Physical violence against lesbian, gay, bisexual, transvestite and transgender individuals from Brazil. Rev Salud Pública [Internet]. 2018 [cited 2020 Mar 03];20(4):445-52. Available from: http://www.scielo.org.co/pdf/rsap/v20n4/0124-0064rsap-20-04-445.pdf

18. Martins-Filho PRS, Mendes MLT, Reinheimer DM, Nascimento Jr EM, Vaez AC, Santos VS, et al. Femicide trends in Brazil: relationship between public interest and mortality rates. Arch Womens Ment Health [Internet]. 2018 [cited 2020 Mar 01];21:579-82. Available from: https://pubmed. ncbi.nlm.nih.gov/29594384/

19. Interamerican Comission on Human Rigths. Violence against lesbian, gay, bissexual, trans and intersex person in the américas. Washington: UNAIDS, OAS oficial records, 2015.

20. Oliveira RNG, Gessner R, Brancaglioni BCA, Fonseca RMS, Egry EY. Preventing violence by intimate partners in adolescence: an integrative review. Rev Esc Enferm USP[Internet]. 2016 [cited 2020 Mar 11];50(1): 134-43. Available from: https://www.scielo.br/pdf/reeusp/v50n1/00806234-reeusp-50-01-0137.pdf

21. Breiding MJ, Basile KC, Klevens J, Smith SG. Economic insecurity and intimate partner and sexual violence victimization. Am J Preventive Medicine [Internet]. 2017 [cited 2020 May 12];53(4):457-64. Available from: https://pubmed.ncbi.nlm.nih.gov/28501239/

22. Hernández W, Durán RL. History matters, but differently: persisting and perpetuating effects on the likelihood of intimate partner violence. J Prev Interv Community [Internet]. 2019 [cited 2020 May 12];47(3):s/n. Available from: https://pubmed.ncbi.nlm.nih.gov/31556804/

23. Ferrari W, Peres S, Nascimento M. Experiment and learning in the affective and sexual life of young women from a favela in Rio de Janeiro, Brazil, with experience of clandestine abortion. Ciênc Saúde Coletiva. 2018;23(9):2937-50. https://doi.org/10.1590/1413-81232018239.11312018

24. Honorato L, Souza A, Santos T, Lopes O, Zukowsky-Tavares C. Violence in childhood and adolescence: profile reported in the mesoregion of the Low Amazon. Arq Bras Psicol [Internet]. 2018 [cited 2020 May 12];70(2):266-84. Available from: http://pepsic.bvsalud.org/pdf/arbp/v70n2/19.pdf

25. Lünnemann MKM, VanderHorst FCP, Prinzie P, Lujik MPCM, Steketee M. The intergenerational impact of trauma and family violence on parents and their children. Child Abuse Neglect [Internet]. 2019 [cited 2020 May 12];96:e104134. Available from: https://www.sciencedirect.com/ science/article/abs/pii/S0145213419303114

26. Houston-Kolnik JD, Todd NR, Greeson MR. Overcoming the "Holy Hush": a qualitative examination of protestant christian leaders' responses to intimate partner violence. Am J Commun Psychol [Internet]. 2018 [cited 2020 May 11];63(2):12278e. Available from: https://onlinelibrary.wiley. com/doi/epdf/10.1002/ajcp.12278

27. Klement KR, Sagarin BJ. Nobody wants to date a whore: rape-supportive messages in women-directed christian dating books. Sexual Cult [Internet]. 2017 [cited 2020 Apr 15];21:205-23. Available from: hhtps://link.springer.com/article/10.1007/s12119-016-9390-x

28. Barret BJ, Peirone A, Cheung CH. Help seeking experiences of survivors of intimate partner violence in Canada: the role of gender, violence severity, and social belonging. J Fam Viol [Internet]. 2020 [cited 2020 Apr 12];35:15-28. Available from: https://link.springer.com/article/10.1007/ s10896-019-00086-8 